\title{
Going Well
}

National Cancer Institute

\section{Source}

National Cancer Institute. Going Well. NCI Thesaurus. Code C90037.

Proceeding in a satisfactory manner; proceeding as expected or planned. 